
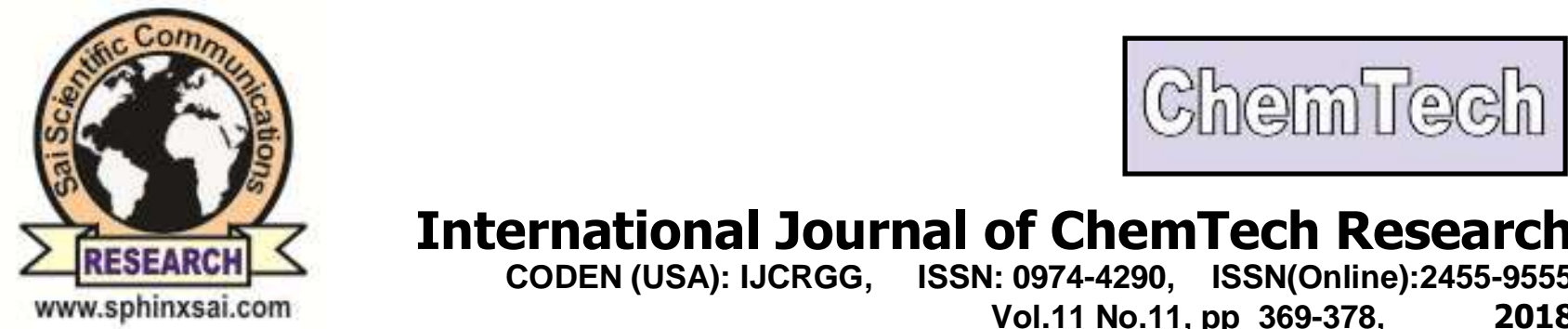

International Journal of ChemTech Research CODEN (USA): IJCRGG, ISSN: 0974-4290, ISSN(Online):2455-9555

Vol.11 No.11, pp 369-378,

2018

\title{
Physical and Chemical Characteristics of Fermented 'Dayak' Wild Yam(Dioscorea hispida Dennst), Purple Yam (Dioscorea alata var. purpurea) and Air Potato (Dioscorea bulbifera L.) Flour as Food Ingredient
}

\author{
Rudito $^{1 \star}$, Netty Maria Naibaho², Suwarto², Jayus ${ }^{3}$, Yuli Witono ${ }^{3}$, \\ Barnatal Saragih ${ }^{4}$, and Enos Tangke Arung ${ }^{5}$
}

${ }^{1}$ Graduate School of Forest Science, Faculty of Forestry, Mulawarman University and Samarinda State Agricultural Polytechnic, Samarinda, Indonesia

${ }^{2}$ Samarinda State Agricultural Polytechnic, Samarinda, Indonesia

${ }^{3}$ Department of Agricultural Product Technology, Faculty of Agricultural Technology, University of Jember, Jember, Indonesia.

${ }^{4}$ Department of Agricultural Technology, Faculty of Agricultural, Mulawarman University, Samarinda, Indonesia.

${ }^{5}$ Department of Forest Product Technology, Faculty of Forestry, Mulawarman University, Samarinda, Indonesia.

\begin{abstract}
Indonesia has many kinds of tuber, especially in the Kalimantan. The kinds of tuber are Dayakwild yam(DioscoreahispidaDennst), purple yam (Dioscoreaalata var. purpurea) and air potato (Dioscoreabulbivera L). However, all these tubers are underutilized. Three types of Dioscoreaspp contain cynamic acid (HCN). It is dangerous to consume it directly. Thisresearchaimed to know the influence of drying temperatur as it impacts onthe physical and chemical characteristics of Dayakwild yam, purple yam and air potato flours. The method used to produce the flour was by introducing heat drying. The experimental design in this research study used was the complete randomized design with about three replications. The drying temperatures in this research were 50,60 , and $70^{\circ} \mathrm{C}$ respectively. The data wereanalysed descriptivelly. The results showed that thehigher temperature thelower colour value,water content, and protein content. The lowest water content and protein content were the pupleyam flour (4.84\%) and air potato flour $(3.96 \%)$ of $70^{\circ} \mathrm{C}$ drying temperature. The air potato flour hadthe highest mineral and fat content with the valuesof $4.63 \%$ and $7.38 \%$ respectively. The carbohydrate had higher percentage than other components. The carbohydrate contents of Dayak wild yam flour with different drying temperatures were $78.15 \%\left(50^{\circ} \mathrm{C}\right), 82.02 \%\left(60^{\circ} \mathrm{C}\right)$, and $82.72 \%\left(70^{\circ} \mathrm{C}\right)$ respectively. The carbohydrate contents of purple yam flour with different

drying temperatures were $77.39 \%\left(50^{\circ} \mathrm{C}\right), 79.46 \%\left(60^{\circ} \mathrm{C}\right)$, and $81.36 \%\left(70^{\circ} \mathrm{C}\right)$ respectively. The carbohydrate content of air potato flour with different drying temperatures were $69.81 \%\left(50^{\circ} \mathrm{C}\right), 73.92 \%\left(60^{\circ} \mathrm{C}\right)$, and $74.34 \%\left(70^{\circ} \mathrm{C}\right)$ respectively. The research also showed that the heating with a temperature of $60{ }^{\circ} \mathrm{C}$ can affect the physical and chemical properties on three flours. The fermentation oftubers can remove the flour's HCN so it can be consumed and as a multi-function ingredient for food.

Keywords : Characteristics, dioscorea sp.,fermented flour.
\end{abstract}




\section{Introduction}

Food is a human need which continues to increase in line with increasing population growth. Increasing population could lead to reduced food availability. One of the effort to meet the food supply is by improving the cultivation and agricultural products which exist in Indonesia such as tubers. Tubers can grow wild in the forest or yard, but still less than optimal utilization (Ndaru, 2012).

Tuber is one of the alternative source of carbohydrates due to the carbohydrate content in the tuber is quite high. Some tubers that can be used optimally are tubers of Dayak wild yam, purple yam and air potato tuber. These three tubers have relatively high carbohydrate content. Dayak wild yam tuber contain carbohydrates as much as 23.23 grams per 100 grams of material (Hariana, 2014), purple yam as much as 19.8 grams (Imanningsih, 2013) and air potato as much as 19.8 grams (Yuniar, 2010).

Tubers have toxic of cyanide acid (HCN), which if consumed in quantities not advisable will lead cyanide poisoning. A food should contain a maximum of $50 \mathrm{ppm}$ or $5 \mathrm{mg} / \mathrm{kg}$ of cyanide acid levels that can be consumed by the body (Harijono and Erriyana, 2008). Based on preliminary research found early, HCN content in Dayak wild yam tuber was $34.61 \mathrm{mg} / 100 \mathrm{~g}$, purple yam of $32.16 \mathrm{mg} / 100 \mathrm{~g}$ and air potatoof $27.8 \mathrm{mg} / 100 \mathrm{~g}$. HCN content of the three tubers is high so that the level is needed to be reduced in order to be consumed. Decreased levels of $\mathrm{HCN}$ can be done in various ways either by fermentation.Fermentation was carried out using fermented cassava yeast for 48 hours, because it is based on preliminary studies that fermentation with yeast is widely available to reduce HCN levels. Decreased levels of HCN from the three tubers were very drastic which was about 1-2 mg/100 grams, so the three tubers can be eaten because it has reached the threshold were safe for consumption.

Tubers have a low shelf life because they contain high waterandare easi to damage. High water level resulting microorganisms grow easily. One effort to reduce the damage is by making the tuber as an intermediate products such as flour. Tuber flour has low water content so that the shelf life time is longer and easier to use or consume. In addition, tuber flour can be used as raw material for the multi-functional food ingredients such as making bread, noodles, cake and so on. The process of making flour through the drying process by using a certain temperature. Drying process has several disadvantages such as changes in the shape, physical and chemical properties, degradation and so on. The drying process can be done in a natural way using sunlight or using the oven. The drying temperature used can not be determined certainty for each food, but depending on the type of foodstuffs to be dried (Novary, 1997).The biological value of dry material food depending on the method of drying (Rosidinet al., 2012). Drying with the high temperatures will reduce the nutritional value contained in food, but if the drying temperature is too low, then the water content of the material is sufficiently high that flour produced has a low shelf life. Therefore,the study are needed to determine the effect of drying temperature on the physical and chemical properties of fermented Dayak wild yam, purple yam, and air potato tuberflour.

\section{Material and Method}

\section{Research Material}

Three research material used Dayakwild yam (DiscoreahispidaDennst), purple yam (Dioscoreaalata var. purpurea) were obtained from Lempake, Samarinda, East Kalimantan and air potato (Discoreabulbifera L.) was obtained from Berau regency, East Kalimantan. Reagen were analitical grade, such as $\mathrm{H}_{2} \mathrm{SO}_{4}, \mathrm{HCl}$, benzene, $\mathrm{NaOH}, \mathrm{AgNO}_{3}, \mathrm{Na}_{2} \mathrm{CO}_{3}, \mathrm{HNO}_{3}$, ferric indicator, silenium, methyl red methyl blue (MMMB), tartaric acid, and distilled water.

\section{Research Design}

The method used to produce the flour was by introducing heat drying. The experimental design in this research study used was the complete randomized design with about three replications. The drying temperatures in this research were $50^{\circ} \mathrm{C}, 60^{\circ} \mathrm{C}$, and $70^{\circ} \mathrm{C}$ respectively. Than the phisycal and chemical characteristics of flours were analysed by AOAC 2005.The data wereanalysed using descriptive analysis. 


\section{Research Implementation}

This study consisted of two stages, namely tubers chip fermentation $\left(1^{\text {st }}\right.$ stage $)$ and the process of making Dayak wild yam, purple yam and air potato tuber flour $\left(2^{\text {nd }}\right.$ stage). The first phase of the study was to choose a good tuber type that is not deformed. The three types of tubers are then washed clean to remove dirt that was attached to the outer skin of the tuber. Dayak wild yam, purple yam and air potato were stripped to separate the skin with tuber meat. Tubers that were clean from the skin were cut and fitted to form a chip. Tubers that have shaped chips were then fermented for 48 hours using fermented cassava yeast to reduce toxins in the tubers. Comparison between ingredients with distilled water is 3:4 with the use of the yeast as much as $10 \%$ of the weight of the material.

The next stage was making tuber flour. The fermentation results of the three types of tubers were dried with different temperatures of 50,60 and $70^{\circ} \mathrm{C}$ for 24 hours. The difference in the temperature of the crusters was to determine the effect of temperature on the physical and chemical properties of Dayak wild yam tuber, purple yam and air potato. After that proceed with the grinding process to reduce the size of the tuber particles. Milling is the process of reducing the size of solid materials with mechanical force into various smaller size fractions. The milling results were then sieved using a 60 mesh sieve so that the flour produced was uniform. The resulting flour was then analyzed for physical and chemical properties.

\section{Result}

\section{Lightness (L)}

The average value of lightness of fermented Dayak wild yam, purple yam and air potato tuber flour as shown in Figure 1 below.

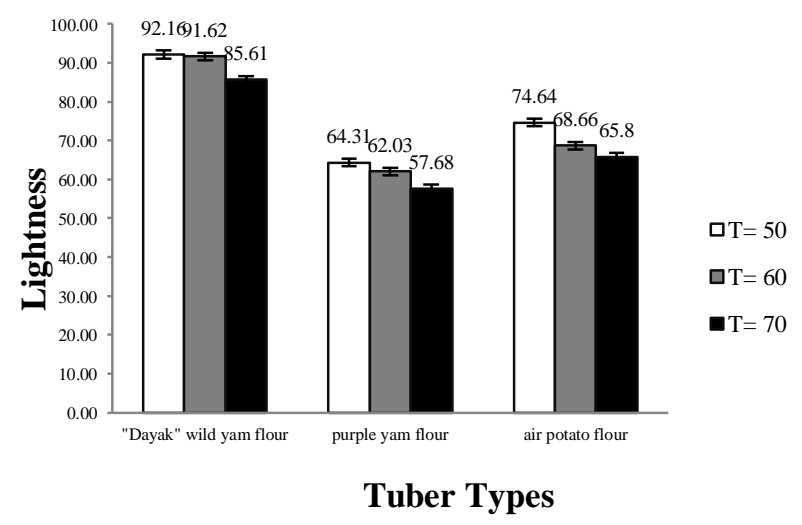

Figure 1. Lightness Value of Fermented DayakWild Yam, Purple Yamand Air Potato Tuber Flour

Figure 1 showed that the highest lightness level of fermented tubers were 92.16 which in $50^{\circ} \mathrm{C}$ of drying temperature and the lowest at $70^{\circ} \mathrm{Cof}$ drying temperature which was 85.61 . It was also occured in fermented purple yam flour and air potatoflour. The fermented purple yam flour lightness level at $50^{\circ} \mathrm{C}$ was 64.31 and decreased to 57.68 at $70^{\circ} \mathrm{C}$. Whereas the fermented air potatoflour was also decreased with increasing the drying temperature, at $50^{\circ} \mathrm{C}$ was 74.64 and the lightnesslevel at $70^{\circ} \mathrm{C}$ decreased to 65.8 .

\section{Water Holding Capacity (WHC)}

The average of WHCof fermented Dayak wild yam, purple yam and air potato tuber flour as shown in Figure 2 below. 


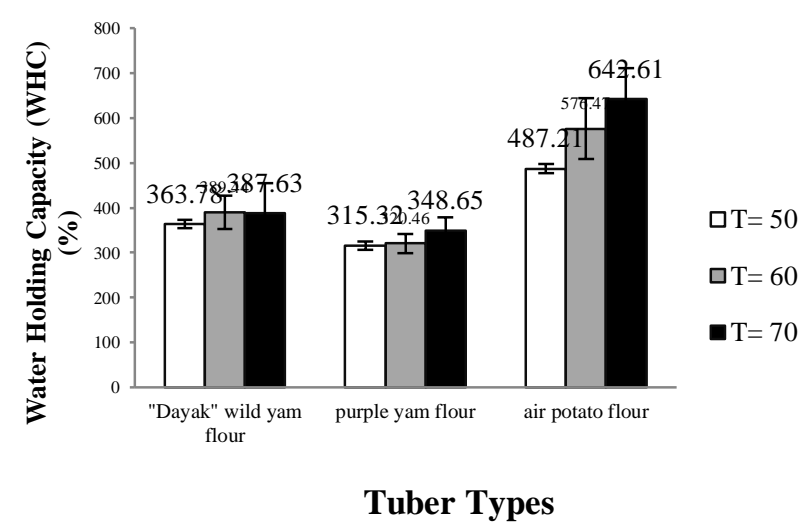

Figure 2. Water Holding Capacity of Fermented DayakWild Yam, Purple Yamand Air Potato Tuber Flour

Figure 2 showed that the fermented air potato which dried at $50^{\circ} \mathrm{C}$ have water holding capacity(WHC) of $487.21 \%$, while the result of drying at $60^{\circ} \mathrm{C}$, the WHC increased to $576.47 \%$ and at the $70^{\circ} \mathrm{C}$ the WHC increased to $642.61 \%$. The fermented purple yam flour which was dried at $50^{\circ} \mathrm{C}$ has the WHCof $315.32 \%$, while when dried at $60^{\circ} \mathrm{C}$ it increased to $320.46 \%$ and at $70^{\circ} \mathrm{C}$ it increased to $348.65 \%$. Whereas the fermented Dayak wild yam flour at a drying temperature of $50^{\circ} \mathrm{C}$ has a WHCof $363.78 \%$, while the drying result at $60^{\circ} \mathrm{C}$ increased to $389.44 \%$ then to387.63\% at $70^{\circ} \mathrm{C}$.

\section{Water Content}

The average of water contentof fermented Dayak wild yam, purple yam and air potato tuber flour as shown in Figure 3 below.

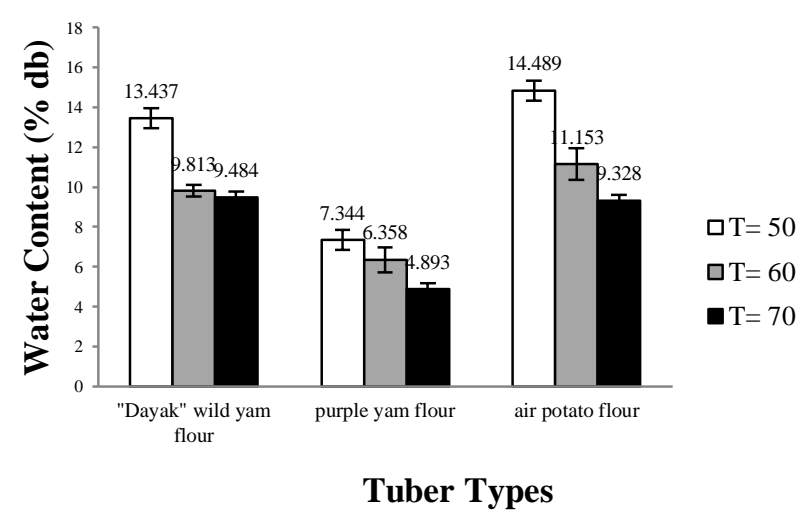

Figure 3. Water Content of Fermented DayakWild Yam, Purple Yamand Air Potato Tuber Flour

Figure 3 showed that the water content of fermentedDayak wild yam flour with drying temperature of $50^{\circ} \mathrm{C}$ was $13.437 \%$; while the drying at $60^{\circ} \mathrm{C}$ the fermented tuberwas $9.813 \%$ and the drying temperature of $70^{\circ} \mathrm{C}$ it decreased to $9.484 \%$. The water content of fermented purple yam flour at $50^{\circ} \mathrm{C}$ was $7.344 \%$, at the drying temperature of $60^{\circ} \mathrm{C}$ the level decreased to 6.358 and to $4.893 \%$ at $70^{\circ} \mathrm{C}$. Whereas the fermented air potatoflour with drying temperature of $50^{\circ} \mathrm{C}$ has a water content of $14.846 \%$, then it decreased to $11.153 \%$ at $60^{\circ} \mathrm{C}$ and then to $9.328 \%$ at $70^{\circ} \mathrm{C}$.

\section{Ash Content}

The average of ash contentof fermentedDayak wild yam, purple yam and air potato tuber flour as shown in Figure 4 below. 


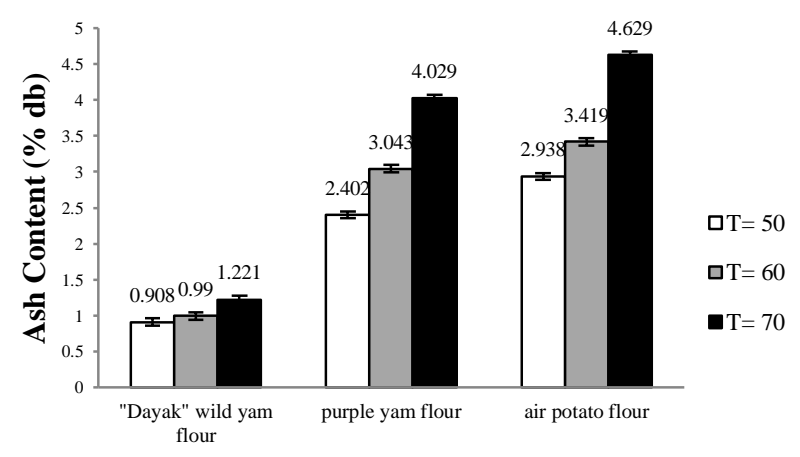

Tuber Types

Figure 4. Ash Content of Fermented Dayak wild yam, Purple Yamand Air Potato Tuber Flour

Figure 4 showed that the fermented Dayak wild yam flour ash content at drying temperature of $50^{\circ} \mathrm{C}$ was $0.908 \%$, then it increased to $0.99 \%$ at $60^{\circ} \mathrm{C}$ and to $1.221 \%$ at $70^{\circ} \mathrm{C}$. The drying of $50^{\circ} \mathrm{C}$, the fermented purpleyam flour hadash content of $2.402 \%$, then it increased to $3.042 \%$ at $60^{\circ} \mathrm{C}$ and to $4.029 \%$ at $70{ }^{\circ} \mathrm{C}$. The fermented air potato hasash content of $2.938 \%$ at $50^{\circ} \mathrm{C}$, then it increased to $3.419 \% 60^{\circ} \mathrm{C}$ and become $4.629 \%$ at drying temperature of $70^{\circ} \mathrm{C}$.

\section{Fat Content}

The average of fat contentof fermentedDayakwild yam, purple yam and air potato tuber flour as shown in Figure 5 below.

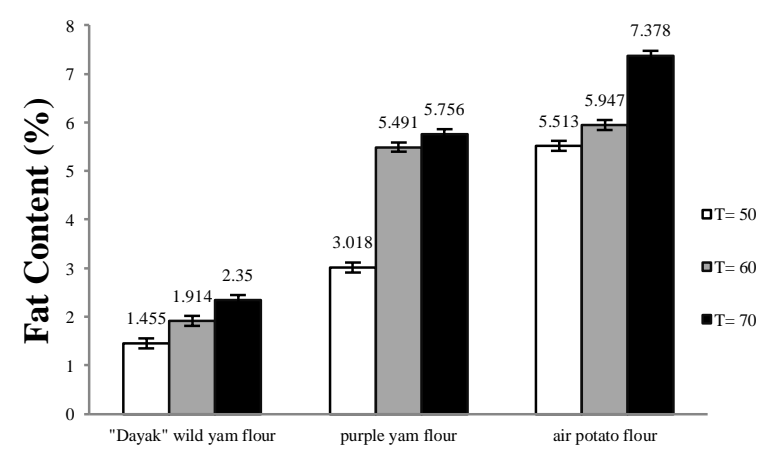

Tuber Types

Figure 5. FatContent of Fermented DayakWild Yam, Purple Yamand Air Potato Tuber Flour

Figure 5 showed that the fermented Dayak wild yam flour fat content with drying temperature of $50^{\circ} \mathrm{C}$ was $1.455 \%$, at $60^{\circ} \mathrm{C}$ it increased to $1.914 \%$ and then become $2.350 \%$ at $70^{\circ} \mathrm{C}$. The fermented purple yam flour at $50^{\circ} \mathrm{C}$ of drying temperature was $3.018 \%$, at the $60^{\circ} \mathrm{C}$ it increased to $5.491 \%$ and then become $5.756 \%$ at $70^{\circ} \mathrm{C}$. The fat content of fermented air potato at $50^{\circ} \mathrm{C}$ of drying temperature was $5.513 \%$, when dried at $60^{\circ} \mathrm{C}$ it increased to $5.947 \%$ and then become $7.378 \%$ at $70^{\circ} \mathrm{C}$.

\section{Protein Content}

The average of protein contentof fermented Dayak wild yam, purple yam and air potato tuber flour as shown in Figure 6 below. 


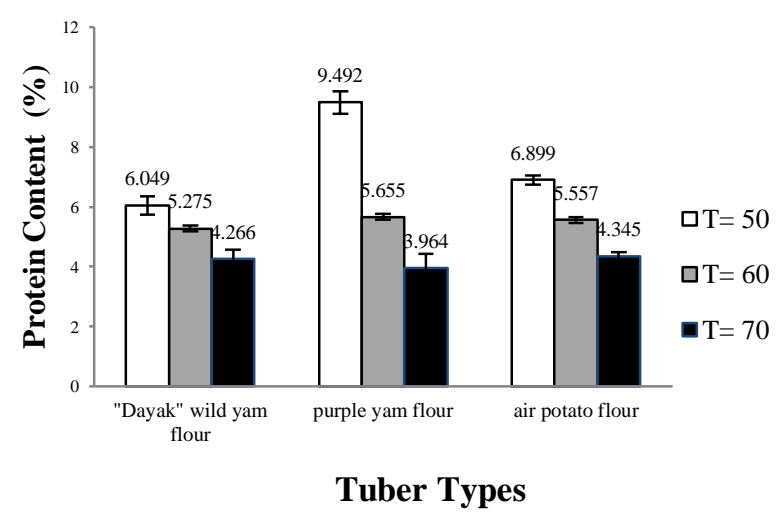

Figure 6. Protein Content of Fermented DayakWild Yam, Purple Yamand Air Potato Tuber Flour

Figure 6 showed that the protein contentof fermented Dayak wild yam flour at $50^{\circ} \mathrm{C}$ of drying temperature was6.049\%, while dried at $60^{\circ} \mathrm{C}$ it decreased to $5.275 \%$ and then to $4.266 \%$ at $70^{\circ} \mathrm{C}$. Whereas the fermented purple yam flour with drying temperature of $50^{\circ} \mathrm{C}$ was $9.492 \%$, at the $60^{\circ} \mathrm{C}$ decreased to $5.655 \%$ and then become $3.964 \%$ at $70^{\circ} \mathrm{C}$. The protein content of fermented air potato at $50^{\circ} \mathrm{C}$ of drying temperature was6.899\%, at the $60^{\circ} \mathrm{C}$ decreased to $5.557 \%$ and then become $4.345 \%$ at $70^{\circ} \mathrm{C}$.

\section{Carbohydrate Content}

The average of carbohydrate contentof fermented Dayak wild yam, purple yam and air potato tuber flour as shown in Figure 7 below.

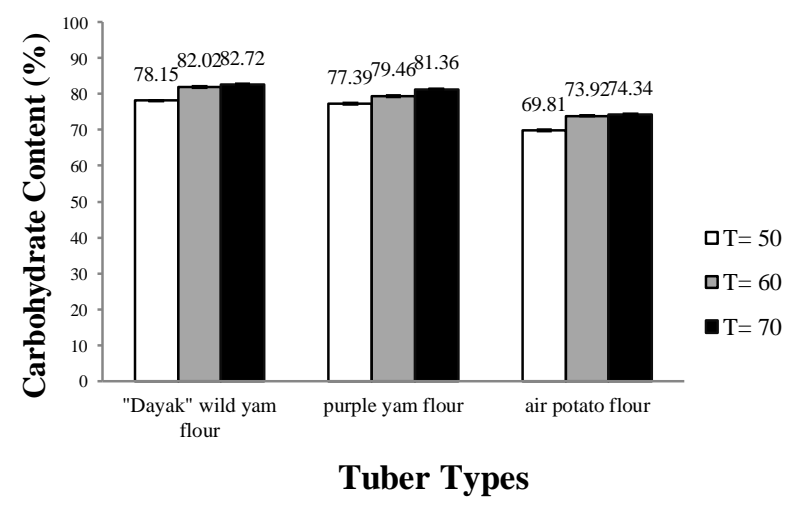

Figure 7. Carbohydrate Contentof Fermented Dayak Wild Yam, Purple Yamand Air Potato Tuber Flour

Figure 7 showed that the fermented Dayak wild yam flour carbohydrate content withdrying temperature of $50^{\circ} \mathrm{C}$ was $78.15 \%$, while dried at $60^{\circ} \mathrm{Cit}$ increased to $82.02 \%$ and then bocome $82.72 \%$ at $70^{\circ} \mathrm{C}$. The fermented purple yam flour at $50^{\circ} \mathrm{Cof}$ drying temperature was $77.39 \%$, when dried at $60^{\circ} \mathrm{C}$ it increased to $79.46 \%$ and then bocome $81.36 \%$ at $70^{\circ} \mathrm{C}$. The fermented air potato flour with drying temperature of $50^{\circ} \mathrm{C}$ was $69.81 \%$, when dried at $60^{\circ} \mathrm{Cit}$ increasedto $73.92 \%$ and then become $74.34 \%$ at $70^{\circ} \mathrm{C}$.

\section{Dietary Fiber Content}

The average of dietary fiber contentof fermented Dayak wild yam, purple yam and air potato tuber flour as shown in Figure 8 below. 


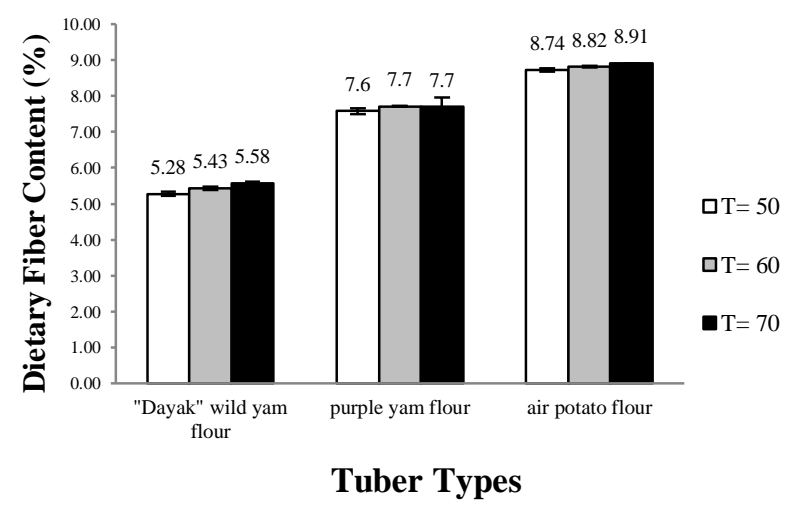

Figure 8. Dietary Fiberof Fermented DayakWild Yam, Purple Yamand Air Potato Tuber Flour

Figure 8 showed that the dietary fiber of fermentedDayak wild yam flour at $50^{\circ} \mathrm{C}$ of drying temperature was $5.28 \%$, when dried at the $60^{\circ} \mathrm{C}$ it increased to $5.43 \%$ and then bocome $5.58 \%$ at $70^{\circ} \mathrm{C}$. The fermented purple yam flour at $50^{\circ} \mathrm{C}$ of drying temperature was $7.6 \%$, when dried at the $60^{\circ} \mathrm{C}$ and $70^{\circ} \mathrm{C}$ it increased to $7.7 \%$. The fermented air potato flour with drying of $50^{\circ} \mathrm{C}$ was $8.74 \%$, when dried at $60^{\circ} \mathrm{C}$ it increased to $8.82 \%$ and then become $8.91 \%$ at $70^{\circ} \mathrm{C}$.

\section{Discussion}

\section{Lightness (L)}

High drying temperature causes the brightness level of the fermented flour is low. This was caused by non-enzymatic browning reactions. Maillard reaction happened when the sugars and proteins in the material is heated, causing a brown color (Winarno, 1991). Browning caused by the formation of brown nitrogenous polymers called melanoidin (DeMann, 1999). The brown color causes the brightness level on flour decreased with increasing drying temperature. Temperature and drying time caused contact between reducing sugars with the amine group become longer. Melanoidin compounds that are formed increasee, causing the brightness decreases.

\section{Water Holding Capacity (WHC)}

Water absorption in food was influenced by the content of starch. Yuliasihet al. (2007) in her research said that starch component affects the absorption of water and swelling of the starch granules. Starch expands quickly at a high temperature so that water absorption is higher (Adebowaleet al., 2005). Dayak wild yam starch is 30.9\% (Sibuea, 2002), and air potato starch is 38.1\% (Shajeela, 2011). Water absorption of food depends on the amount of starch. Water absorption decreasing caused to decrease levels of starch in food (Widaningum, et al, 2005). The ability of starch to absorb water caused large hydroxyl groups in starch (Winarno, 2002).

High drying temperature makes water absorption become high. High temperatures can break hydrogen bonds between molecules. Finally, water is more easily entered. The breaking of hydrogen bonds will form the hydroxyl groups. Hydroxyl group makes higher water absorption(Afrianti,2004). Hydroxyl group is able to pull water. Water absorption was influenced by the content of dietary fiber in the material. High dietary fiber content makes water absorption become high. Dietary fiber contains many hydroxyl groups. Polar free hidroxyl groups are capable of binding more water.

\section{Water Content}

High drying temperature causes water content getting low. High drying temperature causes heat energy increased and made fasting evaporation. Finally, water content getting low on highest drying temperature. The ability of foodstuffs to release water from the surface will increase at high temperatures (Fitriani, 2008). 


\section{Ash Content}

Based on the experiment showed, the higher drying temperature used the ash content of flour was increased. According Darmajana (2007), the higher the drying temperature the ash content increases. It is inversely proportional to the moisture content decreased at high temperatures. The increasing drying temperature, the water content decreases as more and more residue left in the material. The moisture content of dried food stuffs will decrease and cause a higher concentration of materials left behind one mineral (Susanto and Saneto, 1994).

Along with increasing the drying temperature used would increase the ash content offermentedDayak wild yam, purple yam, and air potato flour. The higher drying temperature will increase the ash content due to evaporation of water (Asrawaty, 2011). In accordance opinions of Sudarmadjiet al. (1997), that the ash content depending on the type of material, method, drying time and temperature used. Low temperatures will decompose less the components of ash. The process of heat transfer components potentially to decomposes ash content. Muchtadi (1997) states that the proportion or amount of ash content in food is influenced by several factors, including species, soil nutrient state, the state of maturity of the soil, the climate, the area where growing and planting treatment.

\section{Fat Content}

The fermentation process in tuber cause increased fat content. Increased levels of fat due to the microorganisms in 'NKL' yeast. Microorganisms are living cells that can produce lipids or fats. The resulting fat is referred to as a single cell oil (SCO), which is a euphemism similar to single cell protein that is used to indicate a protein from a single cell microorganisms (Wynn et al., 2005).

The drying temperature influence on the fat content of flour. The higher drying temperature, the fat content of flour also increased. This is presumably the higher the drying temperature the more water-soluble components that lead evaporated fat percentage in the increase because fats cannot dissolve in water. Besides severing of ties lipoproteins that cause lipid loose with protein binding causes increased levels of fat (Almatsier, 2004).

\section{Protein Content}

The protein content of fermented Dayak wild yam, purple yam, and air potato tuber was different after the process of flouring. There is an increase from before and after flouring. The increase was due to the fermentation. According to research Kurniatiet al (2012), the increase of protein content caused by ability of Saccharomyces cerevisiae and Rhizopus orizae to secrete several extracellular enzymes (proteins) into cassava during the fermentation process or the development of Saccharomyces cerevisae and Rhizopusoryzae into cassava in the form of single cell protein for the fermentation process.

The higher temperature of drying, the protein content of the flour was decreased. This happened on three types of flour. Decreased levels of protein due to Maillard reaction in high temperature that causes the loss of amino acid residues. The reaction between reducing sugars and protein is a declining source of nutritional protein value during heating.

Proteins are complex organic compounds that are formed from amino acids linked together by peptide bonds. Amino acids are the main constituent of the protein component. Amino acids are divided into two essential amino acids and non-essential amino acids. Amino acids are generally in the form of powder and easily soluble in water but soluble in nonpolar solvents (Sitompul, 2004), so it is suspected the drying temperature is higher than the water will evaporate and the protein was also more soluble in water also evaporates.

The results of Jacoebet al. (2012) study shows that the steam may affect the content of amino acids in a food. Each amino acid has the characteristics and durability of different. Processing using heat may result in the shrinking amount of amino acids, so that the protein content decreased.

Thepurple yam and air potato flour with a temperature of $60{ }^{\circ} \mathrm{C}$ showed a significant decline from the levels of a protein that was purple yam flour from $9.492 \%$ to $5.655 \%$. It is presumed at $50{ }^{\circ} \mathrm{C}$ the enzyme is still 
actively producing protein and when the drying temperature was increased to $60{ }^{\circ} \mathrm{C}$, the enzymes start slowly so that the inactivated protein levels decreased significantly.

\section{Carbohydrate Content}

Analysis of carbohydrates in the Dayak wild yam, purple yam, and air potato tuber flour use differently calculation method by using the residual value of the final calculation of the water content, ash, fat and protein. The carbohydrate content is influenced by the size of the proportion of water content, ash, fat, and protein. The smaller the proportion of water, fat, protein and ash the higher of carbohydrate.

\section{Dietary Fiber Content}

Dietary fiber contained in Dayak wild yam, purple yam, and air potato flour ranges from 5 to $8 \%$. Dietary fiber in plants is composed of resistant carbohydrates to digestion and absorption in the human small intestine. Dietary fiber is the part that can not hydrolyzed by digestive enzymes (Muchtadi, 2001). Drying temperature does not affect the content of dietary fiber in Dayak wild yam, purple yam, and air potato tuber flour. Dietary fiber in the material will not change by temperature but change by acid and enzymatic hydrolysis.

\section{Conclusion}

Based and the result and discussion, it conclude that higher temperature of drying process was affectted to decreased the lightness level and the protein content. But the ash content and fat content was increased through the high temperature of drying. When the drying temperature was $50{ }^{\circ} \mathrm{C}$, the protein content from purple yam flour of $9.49 \%$ and was decreased to $3.96 \%$ when the temperature was $70{ }^{\circ} \mathrm{C}$. The highest ash and fat content from air potato flour was $4.63 \%$ and $7.38 \%$ repectivelly.

\section{Aknowledgement}

Thanks are conveyed to the Directorate of Research and Community Service, the Indonesia Ministry of Research, Technology and Higher Education which has funded the implementation of this research.

\section{References}

1. Adebowale, K.O, Olu-Owolabi, Olayinka, and Olayide. 2005. Effect of Heat Moisture Treatment and Annealing on Physicochemical Properties of Red Sorghum Starch. African Journal Biotechnology, 4 (9): 923-933.

2. Almatsier, S. 2004. Basic Principles of Nutrition. PT. Gramedia Pustaka Umum. Jakarta.

3. AOAC. 2005. Official Methods of Analysis of the AOAC International. 16th ed. AOAC. Washington DC.

4. Darmajana. A.D. 2007. Effect of Sodium Bisulfite Concentration on Quality of Flour Core Pineapple. National Seminar on Chemical Engineering Gadjah Mada University. Yogyakarta.

5. Hariana, A. 2004. Medicinal Plants and Benefits. Spreading Self-Helpers. Jakarta.

6. Harijono, S.T.A and Erryana. 2008. Detoxification Tuber Wild Yam (Dioscoreahispida Dennst) with Limited Heating in Flour Mills Processing. Journal of Agricultural Technology, 9 (2), 75-78. Malang.

7. Imanningsih, N. 2013. Potential of Dioscorea (Dioscorea alata) Tuber Flour to Prevent Ateroschlorosis in Laboratory Rabbit.Bogor Agricultural University Repository. Bogor.

8. Jacoeb, A. M., Nurjanah, Lingga, Asnita, L. 2012. Characteristics of protein and amino acid crab meat due to steaming. Journal of Fishery Products Processing. 15 (2): 156-163.

9. Muchtadi, D. 2001. Vegetables as a Source of Food Fiber to Prevent Degenerative Disease. Journal of Technology and Food Industry, Vol XII, No. 1 Th 2001.

10. Ndaru, H. 2012. Article on Wild YamTuber (Dioscoreahispida Dennst). Diponegoro University. Semarang.

11. Rachmawan, O. 2001. Drying, Refrigeration and Packaging of Agricultural Commodities. Jakarta: Depniknas. 
12. Rosidin, Kiki, Y., Siti, H. 2012. The Effect of Temperature and Drying Time on the Quality of Frozen Silage Waste Processing (Ranasp) Processing with Rice Addition of Rice. Journal of Study Program of Fishery Products Technology, 1 (1).

13. Sitompul, S. 2004. Analysis of Amino Acids in Fish Flour and Soybean Meal. Buletin of Agricultural Engineering. 9 (1): 33-38.

14. Widaningrum, Widowati S, and Soekarto, S. T. 2005. Soybean Flour Enrichment on Making Wet Noodles with Raw Flour Substituted Substitute Flour Flour. Journal of Post Harvest. 2 (1): 41-48.

15. Winarno, F.G. 2002. Food and Nutrition Chemicals.Gramedia Pustaka Utama. Jakarta.

16. Wynn, James P., and Ratletge, C. 2005. Bailey's Industrial Oil and Fat Products. Sixth Edition, Six Volume Set. Edited by Fereidoon Shahidi. Copyright John Wiley \& Sons, Inc.

17. Yuniar, D.P. 2010. Characteristics of Multiple Ubi Bulbs (Dioscorea spp.) And Potential Study of Inulin Levels. UPN. Surabaya. 